\title{
KONFLIK SOSIAL DALAM NOVEL TENTANG KAMU KARYA DARWIS TERE LIYE : KAJIAN SOSIOLOGI SASTRA
}

\author{
Rahmah Dwi Romadlona, Taufik Nurhadi \\ (Pendidikan Bahasa dan Sastra Indonesia, Fakultas Keguruan dan Ilmu Pendidikan) \\ Universitas PGRI Adi Buana Surabaya \\ Vilflow action@yahoo.com, Taufiknurhadi70@gmail.com
}

\begin{abstract}
ABSTRAK
Penelitian ini bertujuan untuk mendeskripsikan konflik sosial yang terdapat dalam novel About You karya tere liye darwis. sumber data dalam novel Tentang Anda karya tere liye darwis. Penelitian ini adalah teks yang terdapat dalam kumpulan cerita dalam novel, sedangkan data penelitian ini adalah kutipan, deskripsi, dialog dan hal-hal penting lainnya dalam novel About You. Data diperoleh dengan teknik membaca ulang dan mencatat. Data dianalisis dengan pendekatan sosiologi sastra dan teknik analisis deskriptif. Hasil penelitian yang telah dilakukan adalah (1) konflik pribadi adalah konflik antar individu karena adanya permasalahan atau perbedaan pendapat antar pribadi dalam menangani suatu kasus. (2) Konflik politik adalah konflik yang terjadi karena adanya perbedaan kepentingan atau tujuan politik antara orang atau kelompok. (3) Konflik rasial, yaitu konflik antar kelompok ras yang berbeda karena kepentingan dan budaya yang bertabrakan. (4) bahwa konflik sosial antar konflik yang muncul karena adanya perbedaan kepentingan antar kelas dalam masyarakat. serta strategi akuisisi untuk memecahkan masalah yaitu Strategi Menang - Kalah.
\end{abstract}

Kata kunci : konflik sosial, strategi konflik, Tentang Kamu

\section{PENDAHULUAN}

Dalam karya sastra, manusia dan permasalahan hidupnya menjadi subjek penciptaan karya satra itu sendiri, banyak yang dapat diamati dalam diri dan kehidupan manusia, salah satunya adalah konflik sosial. Konflik juga diartikan sebagai suatu bentuk interaksi yang ditandai oleh keadaan yang saling mengancam, mengahancurkan, melukai, dan melenyapkan diantara pihak-pihak yang terlibat. Konflik juga dapat melibatkan perorangan atau kelompok masyarakat, sesuai kenyataan konflik tidak dapat dilepaskan dari dinamika masyarakat. Beberapa penelitian terdahulu yang sudah dilakukan oleh peneliti lain tentang konflik sosial. Pertama jurnal ilmiah oleh Emy Ipritania (UMP;2015) yang berjudul “ Konflik
Sosial Dalam Novel Cintrong PajuPat Karya Suparto Brata (Tinjauan Sosiologi Sastra) “. Hasil dari penelitian ini adalah tentang (1) wujud konflik sosial yang terdapat dalam novel Cintrong Paju-Pat karya Suparto Brata (2) aspek-aspek sosial penyebab terjadinya konflik dalam novel Cintrong Paju-Pat karya Suparto Brata. Penelitian ini termasuk jenis penelitian deskriptif kualitatif. Teknik pengumpulan data pada penelitian ini menggunakan teknik pustaka, teknik simak, dan teknik catat. Hasil penelitian ini meliputi: (1) wujud konflik sosial: perdebatan, pemaksaan, ketidaksopanan, penghinaan, konflik batin, konflik pikiran, perbedaan status sosial, kesombongan, perbedaan gender, pengorbanan, kecurigaan, menfitnah, 
penekanan, kecemburuan;

penyebab terjadinya konflik sosial: perbedaan pendapat, ketidakcocokan, pemaksaan kehendak, konflik batin, prasangka buruk, sindiran, perbedaan status sosial, kecemburuan, sakit hati, dendam, fitnah, kekecewaan; (3) sikap tokoh dalam menghadapi konflik: mengalah, tetap pada pendirian, berani melawan, memaksa, curiga, menentang, menjadi penengah, menghormati, menghargai, marah, semena-mena, menolak, membantah, kaget, meluruskan masalah, merendahkan.

Yang kedua penelitian oleh Anton Setyo Wibowo (UNS ; 2010) yang berjudul " Konflik Sosial Dan Politik Dalam Novel Tanah Api Karya S. Jai ". Yang hasil dari penelitiannya adalah mengetahui konflik sosial dan politik dalam novel Tanah Api karya S. Jai serta mengetahui faktor-faktor yang menyebabkan terjadinya konflik sosial dan politik dalam novel Tanah Api karya S. Jai.

Yang terakhir yakni penelitian

oleh Alfan Noor Rakhmat (Universitas Sebelas Maret ; 2009) yang berjudul " Simbolis Konflik Sosial Dalam Novel Hubbu Karya Mashuri: Sebuah Pendekatan Semiotik “. Dari penelitian tersebut, menghasilkan pengetahuan kepada pembaca tentang (a) Makna yang terkandung dalam novel Hubbu yaitu Islam dan budaya Jawa bisa disatukan yang disimbolkan oleh tokoh utama. Proses penyatuan ini melewati kebimbangan dalam konflik, yang membuatnya semakin yakin jalan yang ditempuhnya. Pemberontakan terhadap nilai-nilai sosial sering terjadi dalam kehidupan sosial. Amanat yang disampaikan adalah berkorban untuk orang lain dapat menumbuhkan rasa tanggung jawab. (b) Nilai-nilai sosial dalam novel $H u b b u$ yang dapat kita ambil adalah dari cerita sastra jendra yang dihadirkan pengarang dalam novel ini. Nafsu-nafsu manusia yang jelek butuh pengendalian dari diri kita sendiri dan sangat tergantung juga dengan lingkungan sekitar. Selain itu, melarikan diri dari masalah bukanlah suatu jalan terbaik yang akhirnya dapat menimbulkan masalah yang baru lagi dikemudian hari.

Dari ketiga penelitian terdahulu diatas, bahwa setiap penelitian itu berbeda. Untuk penelitian ini peneliti membahas hal berbeda dari yang sudah ada. Pada analisis novel menggunakan konflik sosial ini, terdapat beberapa bentuk konflik yang tejadi di setiap bagian dari novel Tentang Kamu seperti konflik politik, konflik antarkelas sosial, konflik rasial, konflik pribadi, dan konflik interaksional. Selain bentuk konflik yang ditemukan, peneliti juga menemukan strategi penyelesaian dari konflik konflik yang telah terjadi. Untuk memilih strategi ini juga tidak asal, tidak sembarangan. Harus melihat konflik terjadi antara siapa dengan siapa, kondisi konflik seperti apa dan konflik yang terjadi seperti apa.

\section{METODE PENELITIAN}

Metode yang digunakan dalam penelitian ini adalah deskriptif kualitatif. Data adalah semua informasi atau bahan deskriptif yang berupa uraian data, ungkapan pernyataan, kata-kata tertulis, dan perilaku yang diamati. Data tersebut tersebut harus dikumpulkan untuk memberikan jawaban terhadap masalah yang dikaji. Dalam penelitian ini data di ambil dari kata kata dan kalimat yang ada pada novel Tentang Кати karya Darwis Tere 
Liye. Pengambilan data ini dipilih karena untuk mengetahui hal hal yang akan di teliti, dalam novel ini banyak kejadian yang berhubungan dengan konflik sosial. Selama berkali kali membaca novel tersebut, kemudian penulis menjadikan data yang sudah terkumpul sebagai objek penelitian.

Sumber data dalam penelitian ini adalah literatur novel berjudul Tentang Kamu karya Darwis Tere Liye. Diterbitkan oleh Replubika Penerbit kav. Polri blok 1 nomor 65 Jagakarsa, Jakarta dan terdiri dari 524 halaman, 33 BAB. Selain itu sumber data berasal dari literatur lain yang sesuai dengan teori yang digunakan penelitian. Teknik pengumpulan data dalam penelitian ini adalah menggunakan teknik pustaka dan membaca berulang ulang serta teknik catat. Teknik pustaka adalah teknik yang menggunakan sumber-sumber tertulis untuk memperoleh data. Teknik membaca ulang adalah suatu metode pemerolehan data yang dilakukan dengan cara membaca sumber data secara berulang -ulang untuk mendapatkan suatu hal yang dicari. Teknik membaca ulang dan teknik catat berarti peneliti sebagai instrument kunci melakukan membaca novel secara cermat, terarah, dan teliti terhadap sumber data primer sebagai sasaran peneliti yaitu yang berupa teks novel Tentang Кати karya Darwis Tere Liye dalam memperoleh data yang diinginkan. Hasil membaca kemudian di catat sebagai sumber data. Teknik yang digunakan dalam penelitian ini studi pustaka. Studi pustaka dilakukan untuk mendapatkan bahan-bahan dan informasi yang berhubungan deengan penelitian. Data yang diperoleh dalam penelitian ini juga diperoleh dengan mendeskripsikan objek penelitian sebagai sumber data, disamping itu juga data-data lain yang bersifat sebagai pendukung yang relevan dengan penelitian tersebut. Teknik yang digunakan dalam analisisis data kualitatif ini adalah reduksi data, penyajian data dan penarikan kesimpulan. Proses ini berlangsung terus-menerus selama penelitian berlangsung.

\section{HASIL PENELITIAN}

Dari hasil analisis terhadap data, peneliti menemukan beberapa jenis atau bentuk konlik sosial yang terjadi pada kisah dalam novel tersebut. Yakni : Konflik pribadi, Konflik politik, Konflik rasial, dan Konflik antar kelas sosial.

\section{Konflik Pribadi}

konflik pribadi yang terjadi yaitu antara ibu tiri Sri Ningsih, Nusi Maratta yang awalnya sayang sekali dengan Sri Ningsih berubah menjadi sangat benci dan meluapkan segala kemarahannya kepada gadis kecil itu, sekecil apapun kesalahan yang dibuat oleh Sri Ningsih akan menjadi kemarahan yang sangat besar dari Nusi Maratta. Sri Ningsih selalu takut dan menurut apa yang dikatakan oelh ibu tirinya itu. Kemarahan ibu tirinya itu begitu meluap - luap, hingga suatu hari Sri Ningsih hanya mendapatkan sedikit bulu babi dan akhirnya Sri Ningsih diusir tidur diluar rumah tanpa ada makan malam untuknya.

"Berapa kali sudah kubilang hah?" Nusi Maratta berteriak, wajahnya merah padam. "maaf bu, aku tidak sengaja." Sri Ningsih gemetar - ketakutan. "matamu ditaruh mana? Kamu kira harga makanan murah? Gratis?" Nusi memukulkan rotan, menghantam telapak tangan Sri. "kamu tahu kenapa bapakmu tenggelam di laut, hah? Tahu tidak?" Sri tidak menjawab. "itu karen kamu, anak 
sial! Anak yang dikutuk." "ibumu! Masih ingat ibumu? Dia mati saat melahirkan anaknya yang dikutuk. Dan setelah itu? Bapakmu mati hanya karena ingin membelikan sepatu baru untukmu. Kamu membawa seluruh kesialan keluarga ini. Kamu membuat semu orang mati!" setengah jam mengepel seluruh lantai, Sri ke belakang, mulai mencuci piring kotor yang menjadi tugasnya sejak pembantu dirumah mereka berhenti. Bertahun tahun berlalu penuh kekerasan. “ hanya ini?” Nusi Maratta melotot, wajahnya merah padam. Sri menunduk, "iya bu. Kata pengepul di pulau seberang harga tetehe sedang jelek." " kamu kira menampungmu dirumah ini biayanya murah? Dan kamu hanya bisa membawa pulang uang hanya ini?" Sri menduk semakin dalam. Dia seharian mengumpulkan bulu babi cukup banyak namun, harganya memang rendah. "kalau kamu sudah tahu harga tetehe rendah, kenapa kamu tidak mencari teripang? Dasar bodoh, gunakan otakmu berpikir." Nusi Maratta mengomel. “ malam ini kamu tidur di luar ! tidak ada dipan gratis." Nusi Maratta membanting pintu depan."

\section{Konflik Politik}

Konflik politik ini terjadi karena perbedaan faham komunis yang dinut oleh Musoh. Ia ingin menghancurkan segala tentang Kiai Ma'sum dan agama. Ia menganggap apa yang dilakukan oleh para Kiai di dunia adalah munafik. Baginya rakyat kecil selalu direndahkan. Ini karena ia berpendapat bahwa para santri yang ada di madrasah Kiai Ma'sum bekerja dan dianggap itu sperti keerja rodi ataupun romusha. Musoh sangat membenci dengan apa saja yang dilakukan oleh Kiai Ma'sum dan para Kiai lainnya. Baginya hanya dialah yang benar. Dan akhirnya Musoh menyerang madrasah Kiai Ma'sum dan membunuh siapapun yang ada disana, terutama keluarga Kiai Ma'sum. Simak sedikit kutipan dibawah :

"kelompok kami telah menguasai Jakarta, Sri. Rakyat berpesta atas kematian jendral - jendral itu. Saatnya pimpinan daerah - daerah bergerak. Sstny kami menghabisi tuan tanah, para kiai, dan militer. Kami akan menyerang madrasah Kiai Ma'sum malam ini, siapapun yang ada disana akan dihabisi" Musoh menjeaska kepada Sri. Sri hanya terdiam ketakutan. "selama kamu disini aman kok Sri. Kita akan menguasai madrasah, kita akan menguasai seluruh harta madrasah, kita akan hidup makmur. Itulah rencana mas Musoh, dia bisa mengambil alih madrasah sialan dari Arifin" Lastri berkata menambahkan omongan Musoh. Hari itu, ditahun 1965 rasa dengki telah menjadi kebencian luar biasa yang bahkan bisa membuat pelakunya tega membabi buta."

3. Konflik Rasial

Koflik rasial yang terjadi selanjutnya antara bangsa jepang dengan bangsa indonesia. Indonesia tidak suka dengan semua produk yang dari jepang. Dan pada saat itu, Sri Ningsih sedang membuka rental penyewaan mobil, semua unit mobil yang digunakan Sri adalah buatan Jepang. Pada saat semua masa mengamuk dan menghancurkan didaerah pasar senen, termasuk kantor rental mobinya Sri. Semua unit mobil hangus dibakar oleh masa. Untuk lebih jelasnya simak kutipan dibawah. "ada yang bakar bakar ban dijalanan, teriak - teriak nyumpahin orang Jepang. Waktu itu perdana menteri Jepang emnag lagi kunjungan ke Indonesia. Orang orang 
menganggap Jepang kebangetan nguasain ekonomi Indonesia. Orang orang pada ngamuk, ngerusak semua barang yang bermerk Jepang, mulai dari mobil, sepeda motor, sampai barang barang elektronik, dibakar atau dilempar ke sungai. Bukan Cuma itu, toko - toko dijarahin, kacau balau. Asap tebal ngepul di Jakarta." Sueb bercerita kepada Zaman."

\section{Konflik Antar Kelas Sosial}

Konflik ini terjadi antara perbedaan kelas sosial, seperti antara atasan dengan bawahan, orang kaya dengan orang miskin dan lain sebagainya. Kali ini konflik yang terjadi pada Sri Ningsih. Kehidupan Sri yang sebenarnya begitu bahagia, status sosialnya diatas, harta yang dimiliki begitu besar dan melimpah. Namun, Sri meninggalkan semuanya dan memilih perjalan yang begitu jauh seorang diri, dari Inggris ke kota Paris. Meninggalkan semua yang ia miliki dan memilih tinggal di panti jompo dekat menara Eiffel. Aimee seorang pegawai panti tidak mengetahui harta yang dimiliki oleh Sri Ningsih. Untuk lebih jelasnya simak kutipan dibawah.

"kami tidak tahu sama sekali jika Ibu Sri Ningsih baru saja melakukan perjalanan panjangratusan kilometer dari London sepanjang malam. Dia ...... dia tidak punya sepeser uangpun, menumpang dari satu mobil ke mobil lain. Termasuk saat menyebrangi Selat Inggris, dia menumpang perahu nelayan, karena ferry tidak mau menaikkan penumpang tanpa tiket. Tiba di daratan Perancis, dia kembali menumpang mobil demi mobil, hingga akhirnya tiba di pinggiran Kota Paris."

\section{PEMBAHASAN}

DR. Nyoman Kutha Ratna dalam bukunya Paradigma Sosiologi Sastra ; 8-10 mengatakan bahwa sosiologi sastra Indonesia dengan sendirina mempelajari hubungan yang terjadi antara masyarakat Indonesia dengan sastra, gejala gejala baru yang timbul sebagai akibat antarhubungan tersebut. Sosiologi sastra yang dikembangkan di Indonesia jelas memberikan perhatian terhadap sastra untuk masyarakat, sastra bertujuan, satra terlibat, sastra kontekstual, dan berbagai proposisi yang pada dasarnya mencoba mengembalikan karya kedalam kompetensi struktur sosial. Penelitian ini, bertujuan untuk mendeskripsikan korelasi antara novel Tentang Kamu karya Darwis Tere Liye serta mendeskripsikan novel tersebut dengan kenyataan yang ada dimasyarakat.

Hasil penelitian ini menunjukkan adanya konflik sosial yang terjadi dibeberapa bagian ceritanya. Diawal sudah dijelaskan ada lima macam konflik sosial namun, yang ditemukan hanya ada empat yaitu; (1) konflik pribadi yaitu konflik yang terjadi di antara orang perorangan karena masalah-masalah pribadi atau perbedaan pandangan antarpribadi dalam menyikapi suatu hal. (2) konflik politik yaitu konflik yang terjadi akibat kepentingan atau tujuan politis yang berbeda antara seseorang atau kelompok. (3) konflik rasial yaitu konflik yang terjadi di antara kelompok ras yang berbeda karena adanya kepentingan dan kebudayaan yang saling bertabrakan. (4) konflik antarkelas soaial yaitu konflik yang muncul karena adanya perbedaan-perbedaan kepentingan di antara kelaskelas yang ada di masyarakat. 
Selain itu, terjadinya konflik pada beberapa bagaian dalam novel itu, ada beberapa strategi yang dilakuakan oleh penulis untuk menanggapi semua kejadian itu. Strategi ini dipilih sesuai dengan kondisi dan situasi masyarakatnya. Strategi yang digunakan adalah Strategi Menang-Kalah (Win-Lose Strategy). Dalam strategi saya menang anda kalah (win lose strategy), menekankan adanya salah satu pihak yang sedang konflik mengalami kekalahan tetapi yang lain memperoleh kemenangan. Beberapa cara yang digunakan untuk menyelesaikan konflik dengan winlose strategy (Wijono, 1993 : 44), dapat melalui: Penarikan diri, Taktiktaktik penghalusan dan damai, Bujukan, Taktik paksaan dan penekanan, yaitu menggunakan kekuasaan formal dengan menunjukkan kekuatan (power) melalui sikap otoriter karena dipengaruhi oleh sifat-sifatindividu (individual traits), dan Taktik-taktik yang berorientasi pada tawarmenawar dan pertukaran persetujuan sehingga tercapai suatu kompromi yang dapat diterima oleh dua belah pihak, untuk menyelesaikan konflik yang berkaitan dengan persaingan terhadap sumber-sumber (competition for resources) secaraoptimal bagi pihak-pihak yang berkepentingan.

\section{SIMPULAN}

Berdasaran hasil penelitian dan pembahasan mengenai konflik sosial dalam novel Tentang Кати karya Darwis Tere Liye pada bab sebelumnya terdapat beberapa hal yang dapat diambil kesimpulan sebagai berikut.

Pertama, dalam novel Tentang

Kати karya Darwis Tere Liye (1) konflik pribadi yaitu konflik yang terjadi di antara orang perorangan karena masalah-masalah pribadi atau perbedaan pandangan antarpribadi dalam menyikapi suatu hal.Misalnya individu yang terlibat utang, atau masalah pembagian warisan dalam keluarga. (2) konflik politik yaitu konflik yang terjadi akibat kepentingan atau tujuan politis yang berbeda antara seseorang atau kelompok. Seperti perbedaan pandangan antarpartai politik karena perbedaan ideologi, asas perjuangan, dan cita-cita politik masing-masing. Misalnya bentrokan antarpartai politik pada saat kampanye. (3) konflik rasial yaitu konflik yang terjadi di antara kelompok ras yang berbeda karena adanya kepentingan dan kebudayaan yang saling bertabrakan. Misalnya konflik antara orang-orang kulit hitam dengan kulit putih akibat diskriminasi ras (rasialisme) di Amerika Serikat dan Afrika Selatan. (4) konflik antarkelas soaial yaitu konflik yang muncul karena adanya perbedaan-perbedaan kepentingan di antara kelaskelas yang ada di masyarakat. Misalnya konflik antara buruh dengan pimpinan dalam sebuah perusahaan yang menuntut kenaikan upah.

Konflik yang terjadi pada tokoh tokoh yang terdapat dalam cerita, yaitu konflik antara Zaman dengan pimpinan lembaga firma, konflik anatara Zaman dengan diri sendiri, konflik antara tokoh Sri Ningsih dengan sahabatnya di pesantren, konflik Sri Ningsih dengan ibu tirinya, konflik Sri Ningsih dengan lingkungan sekitar dan masih ada beberapa konflik lagi yang berhubungan dengan tokoh tokoh sampingan dalam novel.

Kedua, dalam novel Tentang Kamu karya Darwis Tere Liye Strategi yang digunakan adalah 
Strategi Menang-Kalah (Win-Lose Strategy). Dalam strategi saya menang anda kalah (win lose strategy), menekankan adanya salah satu pihak yang sedang konflik mengalami kekalahan tetapi yang lain memperoleh kemenangan.

\section{SARAN}

Berdasarkan simpulan dan mengacu pada manfaat penelitian maka disarankan sebagai berikut :

1. Penelitian ini diharapkan dapat dimanfaatkan bagi pengembangan sastra, khususnya kajian sosiologi sastra sebagai salah satu bentuk analisis terhadap karya sastra yang diddalamnya memberikan kontribusi berbagai nilai yang bermanfaat bagi kehidupan manusia, khususnya dalam bidang sosiologi sastra.

2. Penelitian ini hanya terbatasmengenai konflik sosial yang terdapat dalam novel Tentang Kamu karya Darwis Tere Liye. Oleh karena itu, perlu adanya penelitian selanjutnya terhadap knovel ini dengan menggunakan pendekatan atau sudut pandang yang lain. Selain itu dapat juga ditemukan kelima jenis konflik sosial yang ada pada novel tersebut dan dapat membahas aspek - aspek lain yang juga menarik untuk ditambahkan pada pembahasan novel ini.

3. Dengan menggunakan kajian sosiologi sastra, penelitian ini diharapkan bisa menjadi acuan dalam penelitian lainnya mengenai perilaku, keadaan atau situasi masyarakat.
Terlebih jika itu berkaitan dengan konflik sosial masyarakat.

\section{DAFTAR PUSTAKA}

Aisyah.2009. Konflik Sosial Ditinjau dari Sudut Pandang Agama.

Karya Ilmiah

http://aisyahnursifa96.blogspot. co.id/ diunduh pada $20 \mathrm{Juli}$ 2016.

Budiman, Manneke, dkk. 2013. Sastra Kota (Bunga Rampai Esai Temu Sastra Jakarta). Jakarta : Dewan Kesenian Jakarta.

Damono, Sapardi Djoko.1978. Sosiologi Sastra : Sebuah Pengantar Ringkas. Jakarta: Pustaka Pembinaan dan Pengembangan Bahasa: Departemen Pendidikan dan Kebudayaan.

Endraswara, Suwardi.2013. Metodologi Penelitian Sastra. Jakarta : CAPS (Center for Academic Publishing Service)

Faruk.2013. Pengantar Sosiologi Sastra. Yogyakarta : Pustaka Pelajar Offset

Gibson, James L., et al., 1977. Organisasi: Perilaku, Struktur, Proses. Alih bahasa oleh Adriani. Jakarta: Binarupa Aksara.

Liye, Darwis.2016. Tentang Kamu.Jakarta : Republika Penerbit Matthew B. Miles and A. Michael Huberman.1992. Analisis Data Kualitatif. Jakarta: UI Press.

Ratna, Nyoman Kutha.2013. Paradigma Sosiologi Sastra. Yogyakarta : Pustaka Pelajar

Semi, M Atar. 1988. Anatomi Sastra. Padang: Sidharma

Soekanta.2006. Sosiologi Suatu Pengantar. Jakarta : Raja Grafindo Persada 
Soekanto, Soerjono.2013. Sosiologi Suatu Pengantar. Jakarta : Rajawali Pers

Surbakti, Ramlan. 1992. Memahami Ilmu Politik. Jakarta : Grasindo Syahputra, Iswandi. 2006. Jurnalisme Dmai. Yogyakarta : Pilar Media syahruddin el-fikri. 2016. Rebuplika News

http://www.republika.co.id/ diunduh 20 Juli 2016.
Wellek, Rene dan Austin Warren.1990. Teori Kesusastraan (Terjemahan Melanie Budianta). Jakarta: Gramedia.

Goodreads Author.2016. Rebuplika online http://www.goodreads.com diunduh 20 Juli 2016. 